
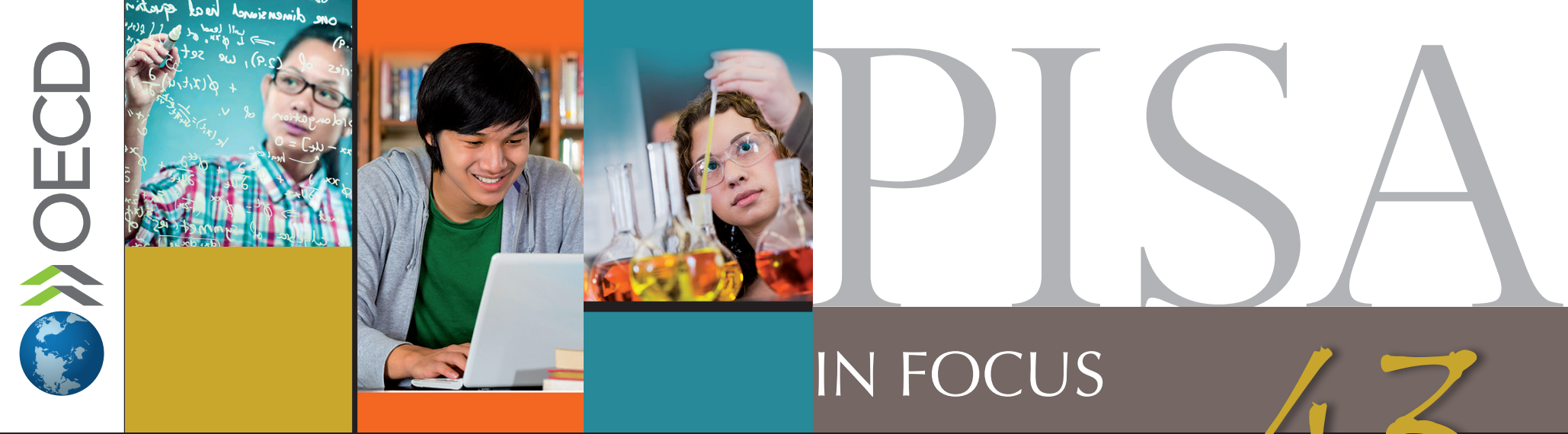

education data education evidence education policy education analysis education statistics education data education evidence education policy

\title{
Are disadvantaged students more likely to repeat grades?
}

- One in eight students across OECD countries has repeated a grade at least once before the age of 15 .

- Many countries reduced the rate of grade repetition between 2003 and 2012.

- One in five disadvantaged 15-year-olds has repeated a grade. Even among students with similar academic performance, the likelihood of repeating a grade is one-and-a-half times greater for disadvantaged students than for advantaged students.

School systems handle underachieving students in different ways. In general, when a student is seen to be performing below the standards for his or her grade, teachers and schools try to provide better learning opportunities, such as by working individually with the student or by offering remedial classes. They may reach out to the student's family to ensure that the student receives encouragement and support. If these measures are not sufficient, some countries sort students into different education tracks according to the students' academic performance. Some countries may require underachieving students to repeat grades, usually with the intention of giving slower students more time to master their coursework and catch up with their peers.

Grade repetition is still used

According to results from PISA 2012, 12\% of extensively in some countries...

15-year-old students across OECD countries reported that they had repeated a grade at least once during their compulsory schooling: $7 \%$ of students had repeated a grade at least once in primary school, $6 \%$ of students had repeated a grade at least once in lower secondary school, and $2 \%$ of students had already repeated an upper secondary grade, even though 15-year-olds have generally just begun their upper secondary education. In Japan, Malaysia and Norway, no 15-year-old student reported that he or she had repeated a grade; and in 24 countries and economies, fewer than $5 \%$ of students reported that they had repeated a grade. 
In contrast, between $20 \%$ and $29 \%$ of students in Chile, France, Germany, the Netherlands and Peru had repeated a grade at least once; between $30 \%$ and $39 \%$ of students in Argentina, Belgium, Brazil, Costa Rica, Luxembourg, Portugal, Spain, Tunisia and Uruguay had repeated a grade at least once; and in Colombia and Macao-China over $40 \%$ of students had repeated a grade at least once.

\section{... but many countries are finding other ways of helping struggling students.}

In practice, however, grade repetition has not shown clear benefits for the students who were held back or for school systems as a whole. And grade repetition is a costly way of handling underachievement: retained students are more likely to drop out, or to stay longer in the school system and spend less time in the labour force. As a result, some countries that had used grade repetition extensively have rejected that policy in favour of more intensive early support for struggling students.

Among the 13 countries and economies that had grade repetition rates of more than $20 \%$ in 2003 , these rates dropped by an average of 3.5 percentage points by 2012 . Rates fell particularly sharply in France, Luxembourg, Macao-China, Mexico and Tunisia. The percentage of 15-year-olds in France, Mexico and Tunisia who reported that they had repeated a grade in primary, lower secondary or upper secondary school was at least ten percentage points lower in 2012 than it was in 2003. Grade repetition rates increased only in Belgium and Spain during the same period.
Grade repetition is prevalent around the globe

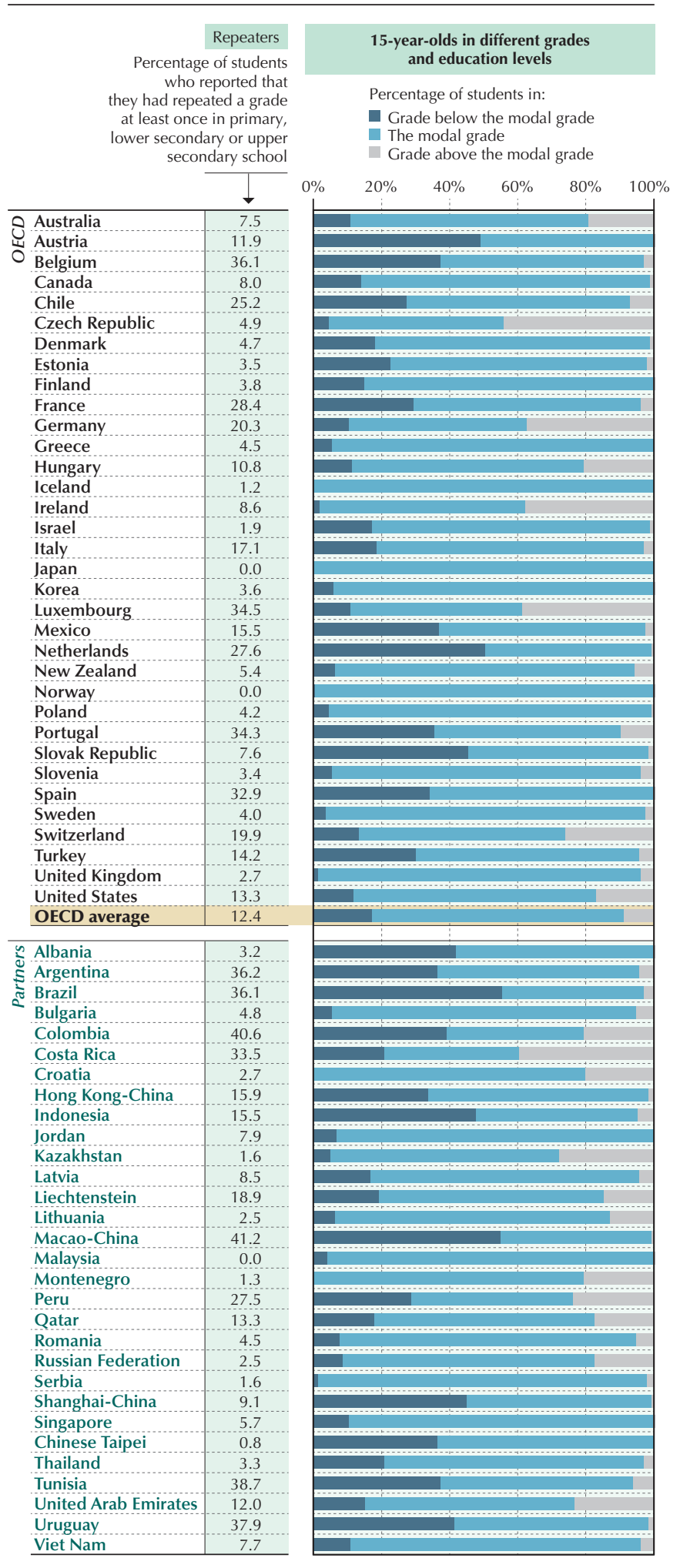

Source: OECD, PISA 2012 Database, Tables IV.2.1, IV.2.2 and IV.2.4.

StatLink न्ता Sस http://dx.doi.org/10.1787/888932957308 


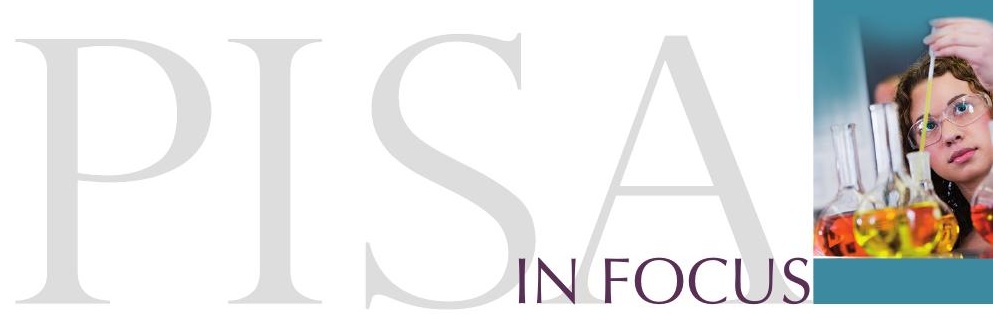

Disadvantaged students are more likely to repeat grades

Increased likelihood of grade repetition among students of similar performance in mathematics, reading and science

\begin{tabular}{|c|c|c|c|c|c|c|}
\hline \multirow[t]{2}{*}{$\begin{array}{c}\text { Disadvantaged students } \\
\text { who repeated a grade } \\
\text { at least once (\%) }\end{array}$} & \multicolumn{6}{|c|}{$\begin{array}{l}\text { Increased likelihood of grade repetition } \\
\text { among disadvantaged students }\end{array}$} \\
\hline & & & 0.5 & 2.0 & 4.0 & $8 .($ \\
\hline Greece & 11 & & & & & \\
\hline Slovak Republic & 21 & & & & & \\
\hline Montenegro & 2 & & & & & \\
\hline Russian Fed. & 6 & & & & & \\
\hline Latvia & 17 & & & & & \\
\hline Viet Nam & 16 & & & & & \\
\hline Spain & 53 & & & & & \\
\hline Shanghai-China & 21 & & & & & \\
\hline Portugal & 56 & & & & & \\
\hline Canada & 14 & & & & & \\
\hline Uruguay & 58 & & & - & & \\
\hline Slovenia & 6 & & & 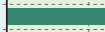 & & \\
\hline Tunisia & 54 & & & 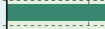 & & \\
\hline Israel & 3 & & & & & \\
\hline Serbia & 3 & & & - & & \\
\hline Liechtenstein & 25 & & & …- & & \\
\hline Bulgaria & 11 & & & $\cdots$ & & \\
\hline Finland & 7 & & & & & \\
\hline Hungary & 21 & & & - & & \\
\hline Jordan & 11 & & & $=$ & & \\
\hline France & 47 & & & & & \\
\hline Romania & 9 & & & 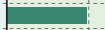 & & \\
\hline Lithuania & 5 & & & 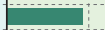 & & \\
\hline Peru & 42 & & & $\cdots$ & & \\
\hline Poland & 8 & & & & & \\
\hline Mexico & 24 & & & & & \\
\hline Luxembourg & 51 & & & 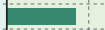 & & \\
\hline Chinese Taipei & 2 & \multirow{5}{*}{\multicolumn{2}{|c|}{\begin{tabular}{|c} 
Disadvantaged \\
students are \\
less likely \\
to repeat grades
\end{tabular}}} & & & \\
\hline Italy & 26 & & & $\ldots$ & & \\
\hline Indonesia & 20 & & & ....... & & \\
\hline Ûnited States & 19 & & & & & \\
\hline UAEE & 20 & & & $\ldots \ldots$ & & \\
\hline Macao-China & 48 & & & ..... & & \\
\hline OECD Average & 20 & & & 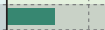 & & \\
\hline Belgium & 53 & & & $\ldots$ & & \\
\hline Hong Kong-Čhina & 21 & & & $\ldots$ & & \\
\hline Qatar & 17 & & & $\ldots$ & & \\
\hline Denmark & 9 & & & $\ldots$ & & \\
\hline Estonia & 5 & & & $\ldots$ & & \\
\hline Costa Rica & 46 & & & - & & \\
\hline Argentina & 47 & & & $\cdots$ & & \\
\hline Sweden & 7 & & & \\
\hline Czech Republic & 10 & & & & & \\
\hline Netherlands & 36 & & & & & \\
\hline Germany & 29 & & & \multirow{3}{*}{\multicolumn{2}{|c|}{$\begin{array}{c}\text { Disadvantaged } \\
\text { students are } \\
\text { more likely }\end{array}$}} & \\
\hline Brazil & 46 & & & & & \\
\hline Kazakhstan & 2 & & & & \\
\hline Colombia & 48 & & & & & \\
\hline Switzerland & 27 & & & & & \\
\hline Australia & 9 & & & & & \\
\hline Croatia & 3 & & - & & & \\
\hline Austria & 17 & & ... & & & \\
\hline Iceland & 1 & & - & & & \\
\hline United Kingdom & 3 & & $\cdots$ & & & \\
\hline Chile & 36 & & .... & & & \\
\hline New Zealand & 6 & & $\ldots$ & & & \\
\hline Ireland & 10 & & $\ldots$ & & & \\
\hline Korea & 3 & & $\ldots \ldots$ & & & \\
\hline Singapore & 8 & & $\ldots \ldots$ & & & \\
\hline Thailand & 3 & & . & & & \\
\hline Turkey & 14 & & & & & \\
\hline
\end{tabular}

Disadvantaged students refers to those in the bottom quarter of the PISA index of economic, social and cultural status (ESCS). The comparison group is advantaged students, i.e. those in the top quarter of the PISA index of economic, social and in darker tons. Proption in darker tones. Proportions of disadvantaged students who repeated a grade Odds ratios are estimated with logistic regression. The independent variables are performance in mathematics, reading and science and indicators for ESCS quarters. Countries and economies are ranked in descending order of the increased likelihood of grade repetition among disadvantaged students.

Source: OECD, PISA 2012 Database.
Not all students are equally likely to repeat grades.

Grade repetition offers no clear benefit to the overall performance of a school system; and because, as PISA results show, socio-economically disadvantaged students are more likely than advantaged students to repeat a grade, grade repetition may also reinforce inequities in the system.

Across OECD countries, one in five $(20 \%)$ socio-economically disadvantaged students reported that they had repeated a grade at least once since they entered primary school, while only $7 \%$ of advantaged students so reported. In Belgium, Luxembourg, Portugal, Spain, Tunisia and Uruguay, more than one in two disadvantaged students reported that they had repeated a grade at least once since they entered primary school. More troubling is that even among students with similar performance in mathematics, reading and science, the likelihood of having repeated a grade is often linked to socio-economic background.

In 33 of the 61 countries and economies analysed, the odds of repeating a grade are significantly higher among disadvantaged students than among advantaged students, after accounting for differences in mathematics, reading and science performance across students. In Portugal and Spain, for instance, when comparing a group of disadvantaged students to an equally proficient group of advantaged students, there are three times more repeaters for every non-repeater in the disadvantaged group than in the advantaged group. On average across OECD countries, disadvantaged students are 1.5 times more likely to repeat a grade than advantaged students who perform at the same level. 
What this shows is that low academic performance is not the only factor that predicts grade repetition; other factors related to socio-economic disadvantage come into play as well. Disadvantaged students who struggle academically may not have the same access to early support and more effective remedial opportunities as advantaged students, so repeating a grade becomes the only alternative for them. Also, grade repetition may be used not so much to help students who are lagging behind, but more as a form of punishment to sanction misbehaviour.
PISA data show that disadvantaged students are significantly more likely to arrive late or to skip classes than their more advantaged peers. It is unclear, however, how retaining students in the same grade might help improve their behaviour in class and their engagement with school. In both cases, disadvantaged students may be deprived of opportunities to learn, thus reinforcing inequities related to socio-economic background.

The bottom line: Grade repetition may not only be ineffective in helping low-achieving students overcome their difficulties at school, but may also reinforce socio-economic inequities. Providing extra teaching time for students who fall behind, adapting teaching to their needs so that they can catch up with their peers, and targeting these efforts where they are most needed is a much better way of supporting students with learning difficulties or behavioural problems.

\section{For more information}

Contact Francesco Avvisati (francesco.avvisati@oecd.org)

See OECD (2014), PISA 2012 Results: What Makes Schools Successful? Resources, Policies and Practices (Volume IV), PISA, OECD Publishing, Paris;

OECD (2011), "When students repeat grades or are transferred out of school: What does it mean for education systems?" PISA in Focus no. 6 (July 2011).

\section{Visit}

www.pisa.oecd.org

www.oecd.org/pisa/infocus

Education Indicators in Focus

Teaching in Focus

\section{Coming next month \\ How is equity in resource allocation related to student performance?}

Photo credit: ( ) khoa vu/Flickr/Getty Images @ Shutterstock/Kzenon @ Simon Jarratt/Corbis

This paper is published under the responsibility of the Secretary-General of the OECD. The opinions expressed and arguments employed herein do not necessarily reflect the official views of OECD member countries.

This document and any map included herein are without prejudice to the status of or sovereignty over any territory, to the delimitation of international frontiers and boundaries and to the name of any territory, city or area.

The statistical data for Israel are supplied by and under the responsibility of the relevant Israeli authorities. The use of such data by the OECD is without prejudice to the status of the Golan Heights, East Jerusalem and Israeli settlements in the West Bank under the terms of international law. 